\title{
Selected Developments in South African Labour Legislation related to Persons with Disabilities
}

\section{Y Basson*}

\section{P.E.R}

Pioneer in peer-reviewed, open access online law publications

Author

Yvette Basson

Affiliation

University of the Western Cape South Africa

Email ywiid@uwc.ac.za

Date published

24 April 2017

Editor Prof W Erlank

How to cite this article

Basson Y "Selected Developments in South African Labour Legislation related to Persons with Disabilities" PER / PELJ 2017(20) - DOI http://dx.doi.org/10.17159/17273781/2017/v20i0a1216

\section{Copyright}

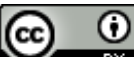

\section{DOI}

http://dx.doi.org/10.17159/1727-

3781/2017/v20i0a1216

\begin{abstract}
In South Africa marginalised groups have historically been afforded legislative protection in order to ensure that the rights of these groups are respected, protected, promoted and fulfilled. Examples of two such groups are older persons, whose rights are provided for in terms of the Older Persons Act 13 of 2006 and children, whose rights are provided for in terms of the Children's Act 38 of 2005. Persons with disabilities have, however, not yet been the subject of dedicated legislation outlining the content of the rights to which they are entitled. As a result of this lack of dedicated legislation, the rights of persons with disabilities are dealt with in a piecemeal fashion, often in disparate pieces of legislation.
\end{abstract}

In addition to this focus on the rights of persons with disabilities, South African labour law has recently undergone extensive amendments. These amendments have led to the rights of persons with disabilities in the workplace being affected substantially. Since these amendments are as yet untested, little scrutiny of these provisions and the effect they may have on persons with disabilities has been undertaken. This article will thus discuss selected amendments of the labour legislation, and interrogate the practical effect these amendments may have on the rights of such persons. Of particular importance for the purposes of this article is the updating of an existing institution known as Sheltered Employment Factories, as well as the introduction of harsher penalties for employers who remain noncompliant with certain provisions of the Employment Equity Act 55 of 1998.

\section{Keywords}

Labour legislation; disability; human rights; employment equity; unemployment; sheltered employment factories. 


\section{Introduction}

The rights of persons with disabilities have recently been under scrutiny, both internationally and locally. In South Africa, marginalised groups have historically been afforded legislative protection in order to ensure that the rights of these groups are respected, protected, promoted and fulfilled. Examples of two such groups are older persons, whose rights are provided for in terms of the Older Persons Act ${ }^{1}$ and children, whose rights are provided for in terms of the Children's Act ${ }^{2}$. Persons with disabilities have, however, not yet been the subject of dedicated legislation outlining the content of the rights to which they are entitled. As a result of this lack of dedicated legislation, the rights of persons with disabilities are dealt with in a piecemeal fashion, often in disparate pieces of legislation.

In addition to the recent focus on the rights of persons with disabilities, South African labour law has recently undergone extensive amendments. These amendments have led to the rights of persons with disabilities in the workplace being affected substantially. Since these amendments are as yet untested, little scrutiny of these provisions and the effect they may have on such persons has been undertaken. This article will thus discuss selected amendments of the labour legislation, and interrogate the practical effect these amendments may have on the rights of persons with disabilities.

There are two primary types of legislation that provide specifically for the rights of persons with disabilities in South Africa. The first is social security legislation and the other is labour legislation. Labour legislation is concerned with the constitutional right to fair labour practices as well as the right not to be discriminated against unfairly in the workplace. ${ }^{3}$ Since disability is a prohibited ground of discrimination, labour legislation provides valuable protection for the rights of persons with disabilities in the workplace.

Labour legislation and social security legislation are linked in a number of ways. One of these is that access to an important component of social security (that is, social insurance ${ }^{4}$ ) is gained through employment; ${ }^{5}$ similarly,

\footnotetext{
* Yvette Basson. LLB, LLM (UWC). Associate Lecturer, University of the Western Cape,

South Africa. Email ywiid@uwc.ac.za

Older Persons Act 13 of 2006.

Children's Act 38 of 2005.

Grogan Employment Rights 10.

Social insurance in South Africa is inextricably linked to employment and includes schemes such as unemployment insurance, compensation for occupational injuries and diseases and retirement funds.

$5 \quad$ Mpedi 2012 Acta Juridica 272.
} 
a lack of access to employment bars access to social insurance. ${ }^{6}$ In this article, current and proposed provisions related to the rights of persons with disabilities in labour legislation will be examined in order to determine how the state intends to increase access to social insurance by means of employment for persons with disabilities.

The Labour Relations Act sparked a period of reform of labour relations which was continued through the introduction of other labour legislation. ${ }^{8}$ The Basic Conditions of Employment Act, ${ }^{9}$ the Employment Equity Act ${ }^{10}$ and the Skills Development Act ${ }^{11}$ all contributed to the first post-apartheid government's aims to "reconstruct and democratise the economy and society as applied in the labour relations arena". ${ }^{12}$

While the aforementioned acts apply equally to all employees, ${ }^{13}$ only two of them make specific, additional provision for the realisation of the rights of persons with disabilities in the workplace and none of these acts extend coverage to persons with disabilities, who are not in formal employment. For this reason, the following discussion will be limited to the Employment Equity Act and the Labour Relations Act. In addition to these, the Employment Services Act ${ }^{14}$ will be discussed, since it is closely linked with the provisions of the Employment Equity Act and is of significance to the rights of persons with disabilities.

\subsection{Approaches to disability}

There are a number of different models of disability. The models used more often, particularly in a legal context, are the medical model, the social model and more recently, the human rights model. The other models have been given status distinct from the social model and the medical model, although each of those can be linked to more widely used models. In order to understand the different approaches to disability, these models are explained.

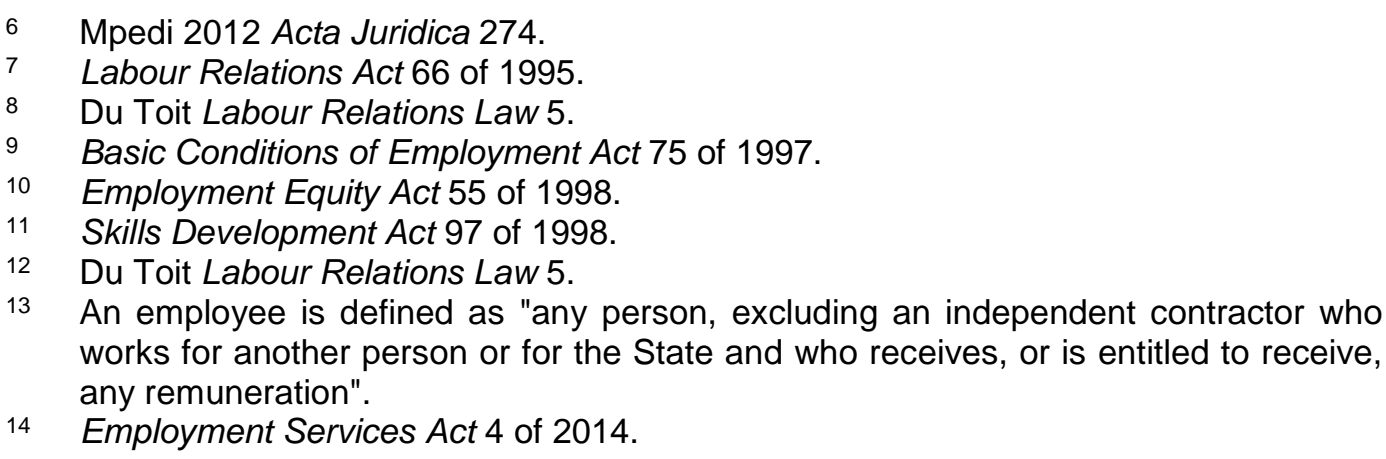
works for another person or for the State and who receives, or is entitled to receive, any remuneration".

14 Employment Services Act 4 of 2014. 


\subsubsection{Medical model}

In terms of the medical model, disability is considered a question of medicine and welfare. ${ }^{15}$ This approach to disability means that persons with disabilities are considered weaker and vulnerable members of society who are unable to provide adequately for themselves and consequently require the assistance of other persons, in particular that of medical professionals. ${ }^{16}$ Assistance so provided would take the form of financial support and care services provided by the community as part of the welfare system of the particular community as well as medical treatment. ${ }^{17}$ The primary focus of the medical model is the involvement of medical professionals in the lives of persons with disabilities, to treat their medical conditions. Thus, in terms of the medical model, the "treatment" and "assistance" of persons with disabilities by others ${ }^{18}$ is paramount. As such, it creates the impression that persons with disabilities induce feelings of sympathy and are not "complete" human beings as a result of their particular medical condition. ${ }^{19}$

\subsubsection{Social model}

The social model differs vastly from the medical model in that the social model approach places much less emphasis on the physical bodies of persons with disabilities. ${ }^{20}$ The approach in terms of the social model is more holistic and is aimed at eliminating the perception that a disability is inherent to the person. ${ }^{21}$ The social model recognises that a disability is the result of a medical condition added to certain attitudinal and environmental factors which create the situation in which a person with a particular medical condition is not able to participate fully and equally in society. ${ }^{22}$

\subsubsection{Human rights model}

Disability is essentially a human rights issue. ${ }^{23}$ This means that the approach taken to disability must address the rights of persons with disabilities and the development of their fundamental rights. In terms of the human rights model, much emphasis is placed on the needs of the individual

\footnotetext{
Office of the President White Paper 13.

Quinn and Degener Human Rights and Disability 10.

Department of Social Development Draft White Paper 31.

Department of Social Development Draft White Paper 31.

Grobbelaar-Du Plessis Gestremdheidsreg 32.

Shakespeare and Watson "Social Model of Disability" 11.

Shakespeare and Watson "Social Model of Disability" 11.

Goering 2002 Kennedy Inst Ethics J 374.

WHO 2013 http://www.who.int/features/factfiles/disability/en/.
} 
and less emphasis is placed on the medical aspects of the disability. ${ }^{24}$ Essentially, the human rights model identifies disability as a result of societal attitudes and external factors, rather than only the medical condition of the particular individual. ${ }^{25}$ The emphasis is thus on the person with a disability as an individual that has the same rights as all other individuals.

It has been suggested that a human rights-based approach to development for persons with disabilities should result in participation, inclusion and the fulfilment of state obligations in relation to persons with disabilities. ${ }^{26}$ The human rights model evolved from the social model and therefore has much in common with the social model, but the human rights model is indicative of the movement towards greater accountability for states to ensure that the rights of persons with disabilities are realised. For these reasons, the human rights model will form the basis of the discussion of the rights of persons with disabilities in this article.

\section{The Labour Relations Act and disability}

An employer is permitted to dismiss employees whose ill-health or injury creates incapacity to perform their duties in accordance with their employment contract. ${ }^{27}$ Such a dismissal will not be unfair, provided that the employer can prove that that there is a link between the ill-health or injury and the employees' inability to perform their duties, and that the employer followed a fair procedure in carrying out the dismissal. ${ }^{28}$ Further protection is provided to persons with disabilities by way of the Code of Good Practice: Key Aspects on the Employment of Persons with Disabilities, which is discussed at a later stage.

In the event that an employee has been fairly dismissed as a result of incapacity due to ill-health or injury, the employee may become entitled to unemployment insurance fund benefits. ${ }^{29}$ In the event that an employee has been unfairly dismissed, he may similarly be entitled to UIF unemployment benefits while challenging the dismissal.

\footnotetext{
24 Quinn and Degener Human Rights and Disability 14.

25 Quinn and Degener Human Rights and Disability 14.

26 Secretary of State for International Development Eliminating World Poverty.

27 Item 11 of Schedule 8 to the Labour Relations Act 66 of 1995 (LRA) provides for the procedure to be followed in dismissing an employee for incapacity due to ill health or illness. Also see generally Davies v Clean Deale CC 199212 ILJ 1230 (IC). Item 11 of Schedule 8 to the LRA.

29 Provided that they comply with all of the eligibility criteria for unemployment benefits.
} 
The importance of the LRA for persons with disabilities therefore relates to situations in which the employee is considered less capable of performing his or her duties as a result of the disability. A person with a disability may not simply be dismissed by an employer if the employer is of the opinion that the employee is no longer working up to a subjective standard. ${ }^{30}$

\section{The Employment Equity Act}

The Employment Equity Act (EEA) was enacted in 1998 with the express purpose of achieving equity in the workplace. ${ }^{31}$ The elimination of unfair discrimination ${ }^{32}$ and the implementation of affirmative action policies ${ }^{33}$ are utilised as mechanisms for achieving this purpose. ${ }^{34}$ In the following paragraphs, both the elimination of unfair discrimination against persons with disabilities and the implementation of affirmative action policies that benefit persons with disabilities will be discussed.

\subsection{Elimination of unfair discrimination}

Section 5 of the EEA provides that "every employer must take steps to promote equal opportunity in the workplace by eliminating unfair discrimination in any employment policy or practice". Further, section 6 provides that

[n]o person may unfairly discriminate, directly or indirectly, against an employee, in any employment policy or practice, on one or more grounds, including race, gender, sex, pregnancy, marital status, family responsibility, ethnic or social origin, colour, sexual orientation, age, disability, religion, HIV status, conscience, belief, political opinion, culture, language and birth or on any other arbitrary ground. ${ }^{35}$

These provisions essentially confirm the constitutional right to equality ${ }^{36}$ and tailor the right to the workplace. Any employment policy or practice which unfairly discriminates on any of the listed grounds or any other arbitrary ground will therefore not be permitted and must be rescinded. ${ }^{37}$

30 If, however, a person with a disability is objectively unable to perform his or her duties, this may amount to poor performance, which is grounds for dismissal in terms of Item 10 of the Code of Good Practice.

31 Section 2 of the Employment Equity Act 55 of 1998 (EEA).

32 Section 2(a) of the EEA.

33 Section 2(b) of the EEA.

34 Du Toit Labour Relations Law 629.

35 Section 6(1) of the EEA was amended by s 3 of the Employment Equity Amendment Act 47 of 2013 to include the phrase "or any other arbitrary ground".

36 Ngwena 2005 Stell LR 210.

37 Hoffmann v South African Airways 200012 BLLR 1365 (CC). 
A noteworthy example of an employment practice that was rescinded as a result of being unfairly discriminatory is found in Hoffmann $v$ South African Airways. The issue was the refusal to appoint a person as part of the cabin crew of the airline as a result of his HIV status. ${ }^{38}$ The basis for the refusal was the fact that the applicant was HIV positive. The airline was then challenged on its decision, on the basis that the decision amounted to unfair discrimination. In reaching its decision, the Constitutional Court considered the right to equality in relation to persons who were HIV positive. ${ }^{39}$ It was held that the refusal to appoint the appellant was unfairly discriminatory, and the Court consequently ordered that the refusal to appoint be set aside and that the appellant be appointed in the position for which he had applied. ${ }^{40}$

Since persons with disabilities have also experienced the systemic disadvantage and discrimination referred to by the Constitutional Court, ${ }^{41}$ it is submitted that any further incidents of the stigmatisation and marginalisation of persons with disabilities, particularly in the workplace, ${ }^{42}$ would amount to unfair discrimination.

\subsection{Affirmative action measures}

The EEA places a duty on designated employers to implement affirmative action measures within their workplace. ${ }^{43}$ Designated employers must, in designing and implementing these affirmative action measures, complete a number of tasks which are prescribed by the EEA. ${ }^{44}$ In the following paragraphs, the procedure prior to, during and following the implementation of an employment equity plan will be discussed. This will clarify the measures put in place to respect, protect, promote and fulfil the rights of designated groups within the workplace. Certain important phrases will be defined before this discussion takes place.

\section{(a) Definition of affirmative action measures}

The use of affirmative action measures to achieve employment equity is alluded to in section 9(2) of the Constitution, which provides that "legislative and other measures designed to protect or advance persons, or categories

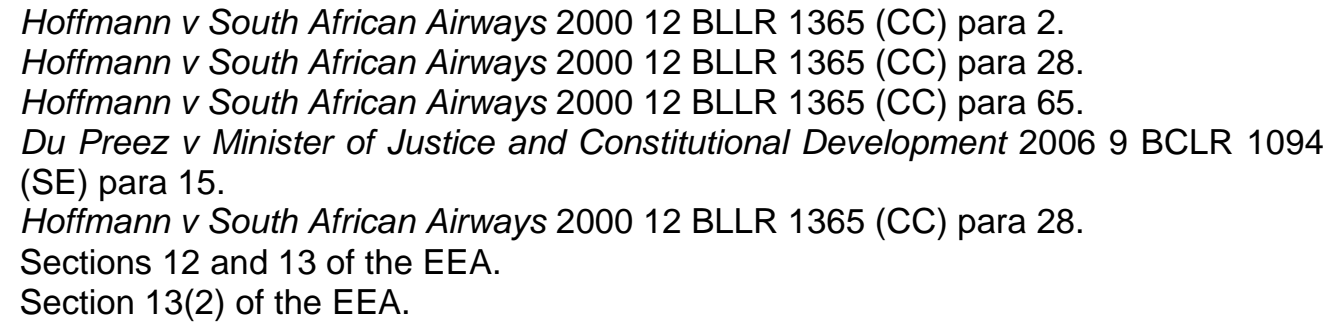


of persons, disadvantaged by unfair discrimination may be taken". ${ }^{45}$ Such measures are therefore intended to promote substantive equality in the workplace and to accurately represent the demographics of various groups in the South African population. ${ }^{46}$ Affirmative action measures are defined as

... measures designed to ensure that suitably qualified people from designated groups have equal employment opportunities and are equitably represented in all occupational levels in the workforce of a designated employer. ${ }^{47}$

Affirmative action measures introduced by an employer must include the identification and elimination of barriers to employment which negatively affect persons from designated groups; must make reasonable accommodation for people from designated groups, which allows for equal opportunity and representation in the workplace; and must lead to further diversity in the workplace and ensure equitable representation of suitably qualified people from the designated groups and all occupational levels in the workplace. ${ }^{48}$

\section{(b) Definition of designated employer}

A designated employer is an employer who employs 50 or more people or employs fewer than 50 employees but has an annual turnover prescribed in Schedule 4 of the EEA; a municipality; an organ of state with certain specific exclusions; or an employer bound by a collective agreement which appoints it as a designated employer. ${ }^{49}$ In addition, an employer who is not a designated employer as defined may choose to comply with the provisions of the EEA in relation to affirmative action measures on a voluntary basis. ${ }^{50}$

\section{(c) Definition of designated groups}

The EEA defines designated groups as "black people, women and people with disabilities". ${ }^{51}$ People with disabilities must therefore be given preferential opportunities for employment as well as advancement within the

45 Section 9(2) of the Constitution of the Republic of South Africa, 1996; Dudley v City of Cape Town 20045 BLLR 413 (LC) para 70; also see Deane 2006 SA Merc LJ 382; Ngwena 2004 JJS 168.

46 Solidarity v Department of Correctional Services 20141 BLLR 76 (LC) para 30; Mushariwa 2012 PELJ 412.

47 Section 15(1) of the EEA, as amended by s 7 of the Employment Equity Amendment Act 47 of 2013.

48 Section 15(2) of the EEA, as amended.

49 Section 1 of the EEA.

50 Section 14 of the EEA.

51 Section 1 of the EEA. 
workplace. ${ }^{52}$ The EEA is thus a crucial part of the protection of the rights of persons with disabilities within the sphere of labour law.

Section 1 of the EEA defines "people with disabilities" as

... people who have a long-term or recurring physical or mental impairment which substantially limits their prospects of entry into, or advancement in, employment. 53

The approach of the legislature in defining "people with disabilities" for the purposes of labour legislation is entirely different to the approach in defining a "disabled person" for purposes of social assistance legislation. In social assistance legislation, a "disabled person" is defined as a person who is at least 18 years old and "is, owing to a physical or mental disability, unfit to obtain by virtue of any service, employment or profession the means needed to enable him or her to provide for his or her maintenance". ${ }^{54}$ It is submitted that the approach taken in labour legislation is the superior one, since the emphasis is placed on the individual, rather than the disability. ${ }^{55}$

(d) Preparing, implementing and reporting on an employment equity plan

The EEA is an important tool in ensuring that serious attempts are made to provide access to employment for designated groups who have historically been marginalised in the workplace. ${ }^{56}$ However, the implementation of affirmative action measures is left to each employer, who is responsible for drafting and implementing an employment equity plan. ${ }^{57}$ In compiling an employment equity plan, the employer must consult with various parties ${ }^{58}$ prior to an analysis of its employment policies, practices, procedures and the working environment, ${ }^{59}$ with a view to preparing and implementing ${ }^{60}$ and reporting on an employment equity plan. ${ }^{61}$ This analysis consists of a survey of each level of employment at the particular workplace and the level of the

52 Harmse $v$ City of Cape Town 2003 ILJ 1130 (LC) para 38; also see Thompson 2007 Obiter 639.

53 Section 1 of the EEA.

54 Section 9 of the Social Assistance Act 13 of 2004.

55 This is evident from the use of the phrase "people with disabilities" which is considered preferable to the term "disabled person" - see, for example, Ngwena 2006 SAJHR 615.

56 Crown Chickens (Pty) Ltd t/a Rocklands Poultry v Kapp 20026 BLLR 493 (LAC) para 35.

57 Section 20 of the EEA.

58 Section 17 of the EEA.

59 Section 19 of the EEA.

60 Section 20(1) of the EEA.

61 Section 21 of the EEA. 
representation of persons from the "designated groups" at each level. Where underrepresentation is identified (by the employer), measures of the employer's own design must be implemented in order to boost the number of people from the "designated groups" at each level of employment. ${ }^{62}$ These measures are compiled into an employment equity plan "which will achieve reasonable progress towards employment equity in that employer's workplace". ${ }^{63}$

\subsection{The importance of the EEA for persons with disabilities}

The EEA assists in (suitably qualified) persons with disabilities entering the workplace through providing some preference to persons with disabilities when applying for positions. This attempts to address the historical exclusion of persons with disabilities from the workplace as a result of the misconceptions and prejudices held by society. Further, the EEA provides for the advancement of persons with disabilities in the workplace by requiring designated employers to interrogate the level of representation of persons with disabilities at all levels of employment. This is indicative of the recognition by the legislature that persons with disabilities should be given opportunities to advance in the workplace, and that persons with disabilities should not be confined to a certain level of employment when they may be suitably qualified for more senior positions.

\subsection{Code of Good Practice: Key Aspects on the Employment of People with Disabilities}

The EEA provides that the Minister of Labour may issue or amend codes of good practice ${ }^{64}$ on matters related to the elimination of unfair discrimination and the implementation of affirmative action measures in the workplace. The Code of Good Practice: Key Aspects on the Employment of Persons with Disabilities (the Code) provides pertinent information for employers who intend to employ persons with disabilities within their workplace as well as for persons with disabilities themselves. ${ }^{65}$ For employers, the Code identifies persons with disabilities for the purposes of the employment equity measures as well as information on how to accommodate persons with disabilities in the workplace. ${ }^{66}$ For persons with disabilities, the Code

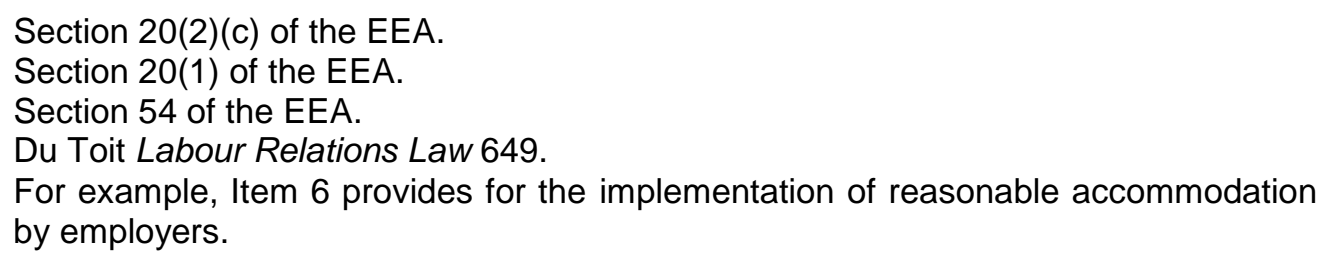


provides information on their existing rights ${ }^{67}$ related to applications for employment or advancement in a particular workplace.

The Code provides that employers must reasonably accommodate persons with disabilities in their workplace during recruitment and selection processes. This reasonable accommodation may take the form of making changes in the working environment; acquiring new equipment or making adaptations to existing facilities and equipment; changing the way work is done and evaluated; and adjusting work time and leave. ${ }^{68}$ Reasonable accommodation includes reorganising work stations, changing training and assessment materials, and restructuring jobs so that non-essential functions are reassigned. ${ }^{69}$ Employers are not required to implement reasonable accommodation in situations where doing so would inflict "unjustifiable hardship" on the employer through being significantly difficult or expensive. ${ }^{70}$

The protection afforded to persons with disabilities in the workplace by the Code of Good Practice therefore consists of a prohibition of dismissal where the ill-health or injury of the employee does not impact on the person's ability to perform his or her duties. ${ }^{71}$ However, the Code of Good Practice also recognises that it is not reasonable to expect an employer to retain an employee who can no longer do the work that is required of that person. ${ }^{72}$

\subsection{The Employment Equity Amendment Act}

In 2014 the Employment Equity Amendment Act $^{73}$ came into operation. ${ }^{74}$ The Act amends numerous provisions of the EEA, including provisions related to the employment and advancement of persons with disabilities in the workplace. The stated purpose of this Act is inter alia to "further regulate the prohibition of unfair discrimination against employees" and "to increase and provide for the increase by the Minister of certain fines which may by

67 Item 3 of the Code provides that the Code does not create additional rights and obligations.

68 Item 6.9 of the Code. This approach places more emphasis on the accommodation of the person with a disability in order for the person to participate fully in the workplace in accordance with the human rights model.

69 Item 6.9 of the Code.

70 Items 6.12 and 6.13 of the Code.

71 Or where the work of the employee may be adapted in such a manner that the employee can perform the assigned duties - see NUM v Libanon Gold Mining Co Ltd (1994) 15 ILJ 585 (LAC).

72 NEHAWU v SA Institute for Medical Research 19972 BLLR 146 (IC).

73 Employment Equity Act 55 of 1998.

74 Employment Equity Amendment Act 47 of 2013. 
imposed under the Act". ${ }^{75}$ In effect, the Employment Equity Amendment Act introduces harsher financial penalties for designated employers who continuously fail to implement their employment equity plans.

The financial penalties imposed in terms of the Amendment Act substantially increase the penalties for non-compliance. An employer who has not previously contravened the sections of the EEA relating to the compilation and implementation of an employment equity plan may be liable to a fine of R1 500000 (previously R500 000); a second contravention may carry a penalty up to R1 800000 (previously R600 000); and successive contraventions may lead to fines ranging from R2 100000 to R2 700000 , depending on the number of contraventions. ${ }^{76}$ These fines are clearly significantly increased, and therefore provide a greater incentive for designated employers to implement their employment equity plans and meet the targets therein. The increase in the penalties imposed for successive instances of non-compliance are also indicative that continuous non-compliance will not be tolerated.

Further, the Employment Equity Amendment Act broadens the definition of unfair discrimination in the workplace. Section 3 of the Act provides that

[a] difference in the terms and conditions of employment between employees of the same employer performing the same or substantially the same work or work of equal value that is directly or indirectly based on any one or more of the grounds listed... is unfair discrimination.

Disability is one of the grounds listed in section 4(1) of the EEA. Prior to this amendment, the EEA did not include any provision relating to the consequences of treating employees performing the same work differently as a result of their disability. Where such an instance of unfair discrimination is identified, the employer is now compelled to progressively reduce the income differentials between the employees. It is submitted that this new definition and remedy for unfair discrimination protects and promotes the right of equal participation in the workplace.

\section{Employment Services Act}

The Employment Services Act (ESA) was promulgated in 2014. One of its aims is to provide for the establishment of schemes to promote the employment of young workers and other vulnerable persons. ${ }^{77}$ The ESA

\footnotetext{
Preamble to the Employment Equity Amendment Act 47 of 2013.

Schedule 1 to the Employment Equity Amendment Act 47 of 2013.

Preamble to the Employment Services Act 4 of 2014 (ESA).
} 
formalises a number of institutions already existing in South Africa and simultaneously introduces a number of new concepts. Examples of the former include the provisions dealing with Productivity South Africa, ${ }^{78}$ and examples of the latter include the establishment of the Employment Services Board. ${ }^{79}$ Both of these types of institutions aim to provide meaningful employment opportunities for persons identified in the ESA.

\subsection{Terminology used in the ESA}

The ESA is concerned with employment opportunities for young workers and vulnerable workers. ${ }^{80}$ The phrase "vulnerable workers" is not defined in the ESA. Persons with disabilities are considered part of the group called "vulnerable workers" since persons with disabilities have been included in the scope of the ESA. The ESA makes specific reference to persons with disabilities in Chapter 6. The term "persons with disabilities" is defined in section 1 of the ESA. For the purposes of the ESA, the legislature has used the same definition of "people with disabilities" as is used in the EEA.

The ESA makes extensive provision for the employment of persons with disabilities in the form of Supported Employment Enterprises. In the following paragraphs the structure and function of this employment service will be discussed.

\subsection{Supported Employment Enterprises}

The ESA makes provision for the establishment of Supported Employment Enterprises (SEE) as a component of national government. ${ }^{81}$ These SEE are intended to

(a) facilitate supported employment;

(b) provide work opportunities for persons with disabilities;

(c) develop and implement programmes that promote the employability of persons with disabilities, including persons with permanent disablement as defined in the Compensation for Occupational Injuries and Diseases Act, 1993 (Act No. 130 of 1993), in the light of their evolving needs in a changing economy; and

\footnotetext{
78 Chapter 5 of the ESA.

79 Section 20 of the ESA.

80 Preamble to the ESA.

81 Section $42(1)$ of the ESA.
} 
(d) perform any other function as may be prescribed by the Minister. ${ }^{82}$

The SEE are intended to be a modification of an existing scheme that provides specifically for the employment of persons with disabilities ${ }^{83}$ in South Africa, namely Sheltered Employment Factories (SEFs). While the functions of the SEE are not very detailed, the content of the functions of SEFs are well-established and will now be discussed, since these functions will become the responsibility of the SEE. 84

SEFs have been in existence in South Africa for a number of years. ${ }^{85}$ As of March 2015 there were twelve SEFs in existence, spanning seven of the nine provinces in South Africa. ${ }^{86}$ However, SEFs were inherited from the previous government and, as such, are now subject to a process which will bring the operation of the proposed SEE in compliance with the Constitution. ${ }^{87}$ The Department of Labour aims to convert the SEFs into bodies that have a definable legal status, which operate efficiently and, most importantly, which advance the active participation in the economy of persons with disabilities.

According to the Department of Labour, the SEFs have been successful in the provision of skills to persons with disabilities. Further, the SEFs have provided employment opportunities for persons with disabilities that may not have been available otherwise. ${ }^{88}$ Despite the proclaimed success of the SEFs, it must be noted that the target for employment of persons with disabilities in the public sector has not been met. ${ }^{89}$ It can therefore be inferred that the SEF concept is not necessarily fully efficient in its current incarnation, although the volume of the products and value added to the economy by the SEFs is evident. ${ }^{90}$ An estimated $10-15 \%$ of the persons

82 Section 43 of the ESA. My emphasis.

83 Memorandum to Employment Services Bill, 2010.

84 Memorandum to Employment Services Bill, 2010.

85 Department of Labour 2012 https://www.labour.gov.za/contacts/statutorybodies/sheltered-employment-factories.

86 Department of Labour 2015 http://www.labour.gov.za/DOL/media-desk/mediastatements/2015/department-of-labour2019s-supported-employment-enterprisessee-move-through-a-new-era-following-the-coming-into-being-of-the-employmentservice-act. ${ }^{86}$ Department of 2012 http://www.labour.gov.za/DOL/contacts/statutory-bodies/sheltered-employmentfactories.

87 Department of Labour 2012 http://www.labour.gov.za/DOL/contacts/statutorybodies/sheltered-employment-factories.

88 Department of Labour 2012 http://www.labour.gov.za/DOL/contacts/statutorybodies/sheltered-employment-factories.

89 Public Service Commission Assessment on Disability Equity.

90 See Department of Labour 2012 https://www.labour.gov.za/ contacts/statutorybodies/sheltered-employment-factories. 
with disabilities in South Africa require an employment environment such as the SEFs. The Department of Labour therefore intends to boost both the capacity and the output of the SEFs in the process of transforming the SEFs into SEEs in terms of the ESA.

\section{(a) Advantages of SEFS}

SEFs have been utilised in a number of foreign jurisdictions in order to provide an environment in which persons with disabilities are taught skills that will enable them to compete in the open labour market. ${ }^{91}$ The SEE are intended to have numerous simultaneous advantages including the provision of skills and gainful employment to persons with disabilities and the addition of valuable labour into the economy. Importantly, the SEE will also result in an increase in the number of persons with disabilities employed in the open labour market. ${ }^{92}$

By better utilising SEFs, the targets related to the employment of persons with disabilities would be reached much quicker than by simply leaving unaltered the current mechanisms aimed at improving the numbers of persons with disabilities in employment. In other words, the introduction of SEE is a concerted effort by the legislature to increase the number of persons with disabilities in formal employment.

\section{(b) Disadvantages of SEFs}

Prima facie, the advent of SEE appears to be largely positive. The SEFs provide a much-needed opportunity for persons with disabilities to participate in the economy while also being given the opportunity to earn a livelihood they may not otherwise have had access to. ${ }^{93}$ However, the use of SEE raises a number of concerns which are discussed below.

The first of the problems with the SEE concept is that it counters the shift towards the social model. Since the human rights model incorporates the notion that persons with disabilities should be given the opportunity to participate equally in mainstream society, ${ }^{94}$ and the SEFs separate persons with disabilities from the much larger portion of the workforce that is not disabled, it becomes apparent that the SEFs do the opposite of what is required in terms of the human rights model. The approach of the SEFs is

\footnotetext{
91 Visier 1998 Int'l Lab Rev 349.

92 Matsepe Sheltered Employment Factories 3.

93 Department of Labour 2012 http://www.labour.gov.za/DOL/contacts/statutorybodies/sheltered-employment-factories.

94 See para 1.1 above.
} 
thus (perhaps inadvertently) based on the medical model, which has been heavily criticised and is generally considered outdated and inappropriate. The UN General Assembly is also quite clear that the approach to disability should be based on the social model. ${ }^{95} \mathrm{It}$ is submitted that the rights to the equality and dignity of persons with disabilities may be negatively impacted by their separation from the mainstream working population by means of the SEF, although the benefits derived from earning an income and participating in the workforce (albeit a small proportion thereof) may offset these negative effects.

The ESA places an emphasis on making it easier for persons with disabilities to enter employment by providing skills and training ${ }^{96}$ rather than making existing employment more accessible to persons with disabilities. Since there are legislative measures that encourage employers to prioritise the employment and advancement of persons with disabilities, ${ }^{97}$ it is submitted that the implementation of the ESA is a positive movement towards the empowerment of persons with disabilities in South Africa. The ESA is, through the use of SEE, providing an additional avenue for persons with disabilities to gain skills and training which would enable greater participation in the economy.

\section{Conclusion}

From the aforementioned discussion, it appears as though there are legitimate and genuine attempts by the legislature to improve the position of persons with disabilities in relation to the workplace. This is evident from the fact that the existing protection of persons with disabilities against unfair dismissal in terms of the LRA is being supplemented by incentives for employers to employ persons with disabilities and ensure that there is equitable representation of persons with disabilities at all levels of employment.

The introduction of harsher penalties for employers who fail to implement their own employment equity plans in terms of the Employment Equity Amendment Act is indicative of the intention of the legislature to ensure the greater integration and advancement of persons with disabilities in the

95 Preamble to the United Nations Convention on the Rights of Persons with Disabilities (2006).

96 Section 43 of the ESA.

97 Such as the Employment Equity Act 55 of 1998. 
workplace. Consequently, these penalties aim to create greater participation for persons with disabilities in the wider non-disabled society.

While the amendments to the Employment Equity Act in relation to the introduction of harsher penalties for non-compliance with employment equity plans is a positive movement towards greater equality for persons with disabilities, the same cannot be said for the provisions of the Employment Services Act. The continued use of sheltered employment institutions (SEFs) results in persons with disabilities being segregated from the mainstream workplace. This continued segregation goes directly against the goal of the full participation and integration of persons with disabilities in mainstream society, including the workplace. It is submitted that the focused provision of skills to persons with disabilities by way of the SEFs is a positive measure aimed at increasing the employment prospects of persons with disabilities. However, the retention of these persons in the SEFs instead of attempting to place them in mainstream workplaces cannot be seen as a movement towards full participation in society.

Considering the statistics available on the representation of persons with disabilities in the workplace, it is clear that equitable representation has not yet been achieved. The fact that persons with disabilities currently experience approximately half the rate of employment of their non-disabled peers is indicative that the attempts by the legislature to ensure equitable representation have not yet yielded the hoped-for results. While it is submitted that the provisions of the Employment Equity Amendment Act will aid in achieving the more equitable representation of persons with disabilities at all levels and in all categories of employment, only time will tell whether these measures will provide the truly equitable representation envisaged by the legislature in the EEA.

\section{Bibliography}

\section{Literature}

Deane 2006 SA Merc LJ

Deane $T$ "The Regulation of Affirmative Action in the Employment Equity Act 55 of 1998: Analyses" 2006 SA Merc LJ 381-388

Department of Social Development Draft White Paper

Department of Social Development Draft White Paper on a National Disability Rights Policy (The Department Pretoria 2014) 
Du Toit Labour Relations Law

Du Toit D (ed) Labour Relations Law $5^{\text {th }}$ ed (Butterworths LexisNexis 2006)

Goering 2002 Kennedy Inst Ethics J

Goering S "Beyond the Medical Model? Disability, Formal Justice, and the Exception for the 'Profoundly Impaired'" 2002 Kennedy Inst Ethics J 373388

Grobbelaar-Du Plessis Gestremdheidsreg

Grobbelaar-Du Plessis I Gestremdheidsreg: 'n Internasionaalregtelike en Regsvergelykende Analise (LLD-thesis University of Pretoria 2010)

Grogan Employment Rights

Grogan J Employment Rights $2^{\text {nd }}$ ed (Juta Cape Town 2015)

Matsepe Sheltered Employment Factories

Matsepe D The Sheltered Employment Factories Transformation Journey Presentation by the Department of Labour (The Department Pretoria 2012)

Mpedi 2012 Acta Juridica

Mpedi LG "The Evolving Relationship between Labour Law and Social Security" 2012 Acta Juridica 270-285

Mushariwa 2012 PELJ

Mushariwa M "UNISA v Reynhardt [2010] 12 BLLR 1272 (LAC): Does Affirmative Action Have a Lifecycle?" 2012 PELJ 412-428

Ngwena 2004 JJS

Ngwena C "Equality for People with Disabilities in the Workplace: An Overview of the Emergence of Disability as a Human Rights Issue" 2004 JJS 167-197

Ngwena 2005 Stell LR

Ngwena C "Interpreting Aspects of the Intersection between Disability, Discrimination and Equality: Lessons from the Employment Equity Act from Comparative Law" 2005 Stell LR210-243

Ngwena 2006 SAJHR

Ngwena C "Deconstructing the Definition of Disability under the Employment Equity Act: Social Deconstruction" 2006 SAJHR 613-646

Office of the President White Paper

Office of the President Integrated National Disability Strategy White Paper (Office of the President Pretoria 1997) 
Public Service Commission Assessment on Disability Equity

Public Service Commission Assessment on Disability Equity in the Public Service (The Commission Pretoria 2008)

Quinn and Degener Human Rights and Disability

Quinn G and Degener T Human Rights and Disability: The Current Use and Future Potential of United Nations Human Rights Instruments in the Context of Disability (United Nations New York 2002)

Secretary of State for International Development Eliminating World Poverty Secretary of State for International Development Eliminating World Poverty: Making Globalisation Work for the Poor - White Paper on International Development (The Stationary Office London 2000)

Shakespeare and Watson "Social Model of Disability"

Shakespeare T and Watson N "The Social Model of Disability: An Outdated Ideology?" in Barnartt SN and Altman BM (eds) Exploring Theories and Expanding Methodologies: Where We are and Where We Need to Go (JAI Amsterdan 2001) 9-28

Thompson 2007 Obiter

Thompson D "Affirmative Action: Only a Shield? Or Also a Sword?" 2007 Obiter 636-646

Visier 1998 Int'l Lab Rev

Visier L "Sheltered Employment for Persons with Disabilities" 1998 Int'l Lab $\operatorname{Rev} 347-365$

\section{Case law}

Crown Chickens (Pty) Ltd t/a Rocklands Poultry v Kapp 20026 BLLR 493 (LAC)

Davies v Clean Deale CC 199212 ILJ 1230 (IC)

Du Preez v Minister of Justice and Constitutional Development 20069 BCLR 1094 (SE)

Dudley v City of Cape Town 20045 BLLR 413 (LC)

Harmse v City of Cape Town 2003 ILJ 1130 (LC)

Hoffmann v South African Airways 200012 BLLR 1365 (CC) 
NUM v Libanon Gold Mining Co Ltd 199415 ILJ 585 (LAC)

Solidarity v Department of Correctional Services 20141 BLLR 76 (LC)

\section{Legislation}

Basic Conditions of Employment Act 75 of 1997

Children's Act 38 of 2005

Constitution of the Republic of South Africa, 1996

Employment Equity Act 55 of 1998

Employment Equity Amendment Act 47 of 2013

Employment Services Act 4 of 2014

Employment Services Bill, 2010

Labour Relations Act 66 of 1995

Older Persons Act 13 of 2006

Skills Development Act 97 of 1998

Social Assistance Act 13 of 2004

International instruments

United Nations Convention on the Rights of Persons with Disabilities (2006)

\section{Internet sources}

Department of Labour 2012 https://www.labour.gov.za/contacts/statutorybodies/sheltered-employment-factories

Department of Labour 2012 Sheltered Employment Factories https://www.labour.gov.za/contacts/statutory-bodies/shelteredemployment-factories accessed 25 April 2016

Department of Labour 2015 http://www.labour.gov.za/DOL/mediadesk/media-statements/2015/department-of-labour2019s-supportedemployment-enterprises-see-move-through-a-new-era-following-thecoming-into-being-of-the-employment-service-act 
Department of Labour 2015 Department of Labour's Supported Employment Enterprises (SEE) Move Through a New Era Following the Coming into Being of the Employment Service Act http://www.labour.gov.za/DOL/media-desk/mediastatements/2015/department-of-labour2019s-supported-employmententerprises-see-move-through-a-new-era-following-the-coming-into-beingof-the-employment-service-act accessed 25 April 2016

WHO 2013 http://www.who.int/features/factfiles/disability/en/ World Health Organisation 201310 Facts on Disability http://www.who.int/features/factfiles/disability/en/ accessed 25 April 2016

\section{LIST OF ABBREVIATIONS}

$\begin{array}{ll}\text { EEA } & \text { Employment Equity Act } \\ \text { ESA } & \text { Employment Services Act } \\ \text { Int'l Lab Rev } & \text { International Labour Review } \\ \text { JJS } & \text { Journal for Juridical Science } \\ \text { Kennedy Inst Ethics J } & \text { Kennedy Institute of Ethics Journal } \\ \text { LRA } & \text { Labour Relations Act } \\ \text { PELJ } & \text { Potchefstroom Electronic Law Journal } \\ \text { SA Merc LJ } & \text { SA Mercantile Law Journal } \\ \text { SAJHR } & \text { South Africa Journal on Human Rights } \\ \text { SEE } & \text { Supported Employment Enterprises } \\ \text { SEF } & \text { Sheltered Employment Factories } \\ \text { Stell LR } & \text { Stellenbosch Law Review } \\ \text { UN } & \text { United Nations } \\ \text { WHO } & \text { World Health Organisation }\end{array}$

